Int. J. Morphol.,

32(2):608-613, 2014.

\title{
Histological Description of Oogenesis in Chiton virgulatus (Mollusca: Polyplacophora)
}

\author{
Descripción Histológica de la Ovogénesis de Chiton virgulatus (Mollusca: Polyplacophora) \\ Nurenskaya Vélez-Arellano*; Mineko Shibayama**; Esperanza Ortíz-Ordoñez ${ }^{* * *}$; Angélica Silva-Olivares**; \\ Marcial Arellano-Martínez,****** \& Federico García-Domínguez ${ }^{*, * * * *}$
}

\begin{abstract}
VÉLEZ-ARELlANO, N.; SHIBAYAMA, M.; ORTÍZ-ORDOÑEZ, E.; SILVA-OLIVARES ANGÉLICA; ARELLANOMARTÍNEZ, M. \& GARCÍA-DOMÍNGUEZ, F. Histological description of oogenesis in Chiton virgulatus (Mollusca: Polyplacophora). Int. J. Morphol., 32(2):608-613, 2014.
\end{abstract}

SUMMARY: This paper describes the oogenesis of Chiton virgulatus, based on histological observations under transmission and scanning electron microscopy. Three oocyte types were identified: i) previtellogenic oocytes with a mean diameter of $50 \pm 20.5 \mu \mathrm{m}$, surrounded by elongated follicular cells of approximately $5 \mu \mathrm{m}$, ii) immature vitellogenic oocytes with a mean diameter of $113 \pm 15.3 \mu \mathrm{m}$ and small cytoplasmic projections denoting the onset of the oocyte hull development; adjacent to each projection are pores approximately $0.7 \mu \mathrm{m}$ in diameter, and iii) mature vitellogenic oocytes with a mean diameter of $146 \pm 24.8 \mu \mathrm{m}$; the oocyte cytoplasmic projections grow and its apical zone becomes trident-shaped; follicular cells adopt a bulbous shape due to the growth of the elongation and can reach up to $20 \mu \mathrm{m}$ in length. The morphology and ultrastructure of the projections of the mature vitellogenic oocyte, as well as the size of pores at their base, are specific to $C$. virgulatus; therefore, these features could be used in taxonomic or fertilization studies.

KEY WORDS: Egg hull; Vitellogenesis; Ultrastructure.

\section{INTRODUCTION}

A number of studies of oogenesis in polyplacophorans using histological and histochemical techniques have been published, in which three or four different cell types are distinguished based on their shape and size, as well as on the development of an extracellular coating (Cowden, 1961; Deshpande \& Nagabhushanam, 1983), known as egg hull, made up of numerous mucopolysaccharides and protein projections secreted by follicular cells and the oocyte itself, with conspicuous projections shaped as domes, cups, cones, fins, spiral tips or spines (Eernisse \& Reynolds, 1994; Buckland-Nicks \& Hodgson, 2000; Sotil, 2004; BucklandNicks, 2008; Buckland-Nicks \& Brothers 2008; BucklandNicks \& Reunov, 2009; Ituarte et al., 2010; Liuzzi \& Zelaya, 2013). It has also been reported that in some species of the Lepidochitonidae family, the egg projections have been lost almost completely (Eernisse, 1988; Buckland-Nicks \& Hodgson; Buckland-Nicks). The morphology of projections varies between species and, thus, these are judged to be useful as a taxonomic trait (Sirenko, 1998, Buckland-Nicks \& Hodgson,; Buckland-Nicks \& Brothers; Buckland-Nicks).
This paper investigates, for the first time, the oogenesis in Chiton virgulatus Sowerby, 1840. This will further the knowledge of this species' reproductive biology and will serve as basis for future taxonomic studies.

\section{MATERIAL AND METHOD}

Specimens of $C$. virgulatus were collected at the Balandra rocky coast $\left(110^{\circ} 19^{\prime} 45^{\prime \prime} \mathrm{W}, 24^{\circ} 19^{\prime} 22^{\prime \prime} \mathrm{N}\right)$, a locality situated in Bahía de La Paz, Baja California Sur, Mexico. During reproductive season (June and July), twenty specimens were collected manually from the intertidal zone, transported to the laboratory, killed and dissected. To observe the histological characteristics of oocytes a portion of each specimen's gonad was fixed in $10 \%$ formalin (prepared with seawater) and embedded in paraffin to obtain $7 \mu \mathrm{m}$-thick sections, which were stained with hematoxylin-eosin. The ultrastructure of oogenesis was described using transmission

\footnotetext{
* Instituto Politécnico Nacional, Centro Interdisciplinario de Ciencias Marinas, Instituto Politécnico Nacional, La Paz, México.

** Departamento de Infectómica y Patogénesis Molecular, Centro de Investigación y de Estudios Avanzados, Instituto Politécnico Nacional, México D.F., México.

**** Instituto Politécnico Nacional, Escuela Nacional de Ciencias Biológicas, México D.F., México.

${ }^{* * * * *}$ Becario Comisión de Fomento y Actividades Académicas del IPN, México D.F., México.
} 
electron microscopy and gonad fragments of approximately $1 \mathrm{~mm}^{3}$. These gonad fragments were fixed in $2.5 \%$ glutaraldehyde in $0.2 \mathrm{M}$ sodium cacodylate buffer for two hours at $4^{\circ} \mathrm{C}$, then post-fixed in $2 \%$ osmium tetraoxyde and dehydrated immediately after; afterwards, the alcohol was replaced with propylene oxide, and were finally embedded in Spurr resin. Semi-thin sections were obtained and stained with toluidine blue; afterwards, fine sections were contrasted with uranyl acetate and lead citrate, to be observed under a Jeol 1400X transmission electron microscope. To describe the morphology of the cells, in parallel, samples of gonadal tissue measuring approx. $5 \mu \mathrm{m}^{3}$ were fixed in $2.5 \%$ glutaraldehyde in filtered sea water, rinsed in saline solutions of decreasing concentration (from 37 ups to distilled water), then predehydrated through ethyl alcohol of increasing concentrations (30 to $100 \%$ ), and dried up to the $\mathrm{CO}^{2}$ critical point. Samples were then placed in an osmium-vapor saturated chamber, subsequently coated with palladium and finally observed and their images captured with a Hitachi S- 3000N scanning electron microscope and a Quartz PCI image processor.

\section{RESULTS}

Oogenesis in C. virgulatus starts in the germinal tissue adjacent to connective tissue invaginations that project towards the gonad center. Vitellogenic and previtellogenic oocytes are formed by meiosis of diploid cells located in the connective tissue. In this paper, three different oocyte types are identified based on morphology and ultrastructure: previtellogenic oocytes (Figs. 1 and 2), immature vitellogenic oocytes (Figs. 3 and 4) and mature vitellogenic oocytes (Figs. 5,6 and 7).

Previtellogenic oocytes range between 19 and 140 $\mu \mathrm{m}$ in diameter, averaging $50 \pm 20.5 \mu \mathrm{m}$; these are basophilic and with a highly vacuolated cytoplasm; the chondriome is scattered throughout the cytoplasm (Figs. 1A and 2A). Previtellogenic oocytes are surrounded by elongated follicular cells about $5 \mu \mathrm{m}$ in size (Fig. 2B), have a flattened nucleus and an abundant smooth endoplasmic reticulum.

Vitellogenic immature oocytes range from 74 to 160 $\mu \mathrm{m}$ in diameter, averaging $113 \pm 15.3 \mu \mathrm{m}$; these are acidophilic and typically display small cytoplasmic projections formed by tubular filaments, which denote the onset of the oocyte hull development; as projections grow, follicular cells become deformed (Fig. 3B). Oocyte projections are constituted by three layers: inner, middle and outer layers, with microvilli present at the basal zone where the growth of cytoplasmic projections starts (Fig. 3D). Pores of about $0.7 \mu \mathrm{m}$ in diameter are observed adjacent to each projection (Fig. 4). Cytoplasmic vacuoles are fewer than in previtellogenic oocytes, as vitelline platelets of various shapes and sizes start to develop as the oocyte matures (Fig. 3B).

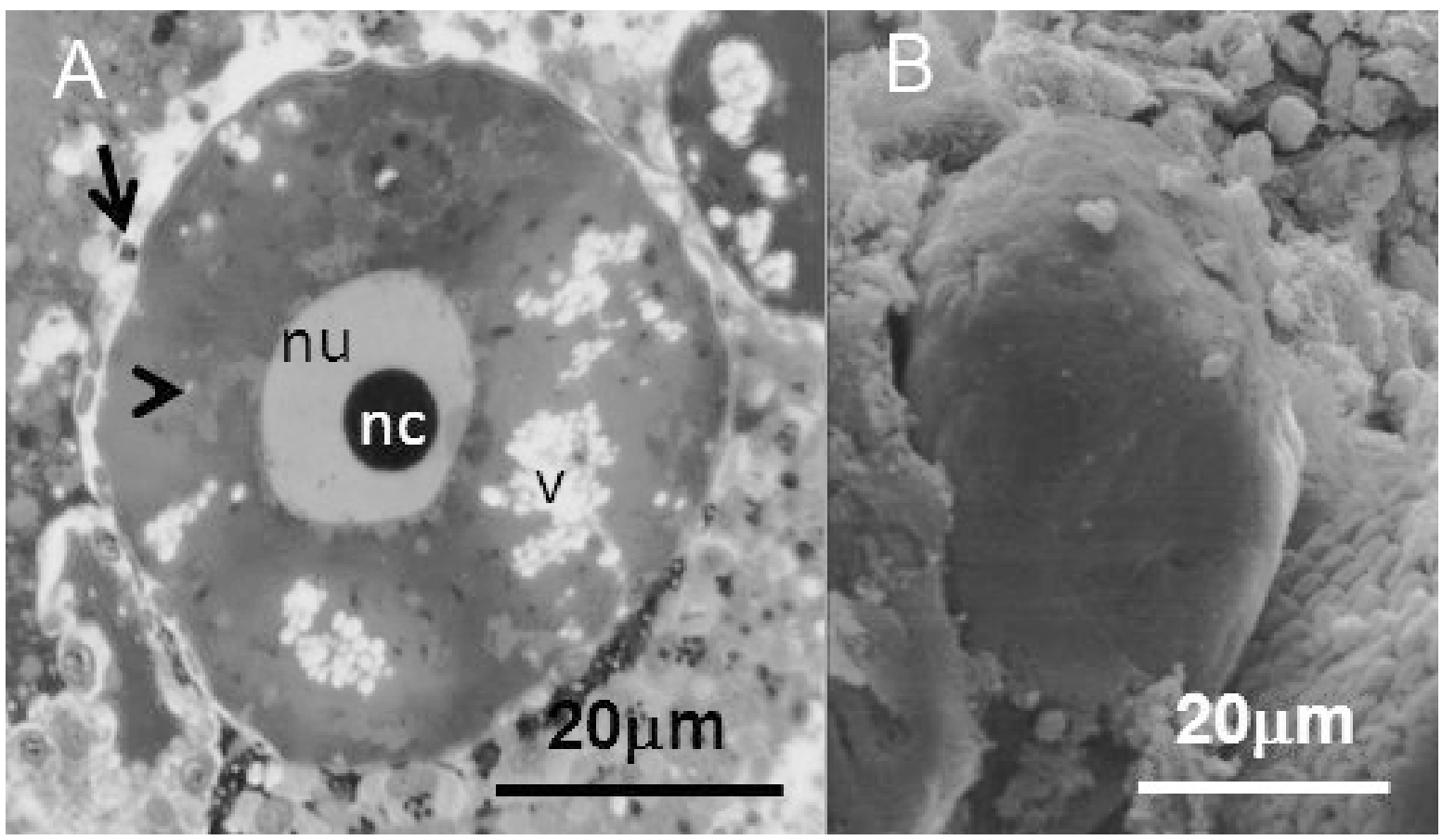

Fig. 1. Previtellogenic oocyte of Chiton virgulatus. A) toluidine blue staining, (nu) nucleus, (nc) nucleolus, (v) vacuole, (arrowhead) chondriome, (arrow) follicular cell. Bar scale: $20 \mu \mathrm{m}$. B) Morphology of a previtelogenic oocyte. Scanning electron microscopy. Bar scale: $20 \mu \mathrm{m}$. 


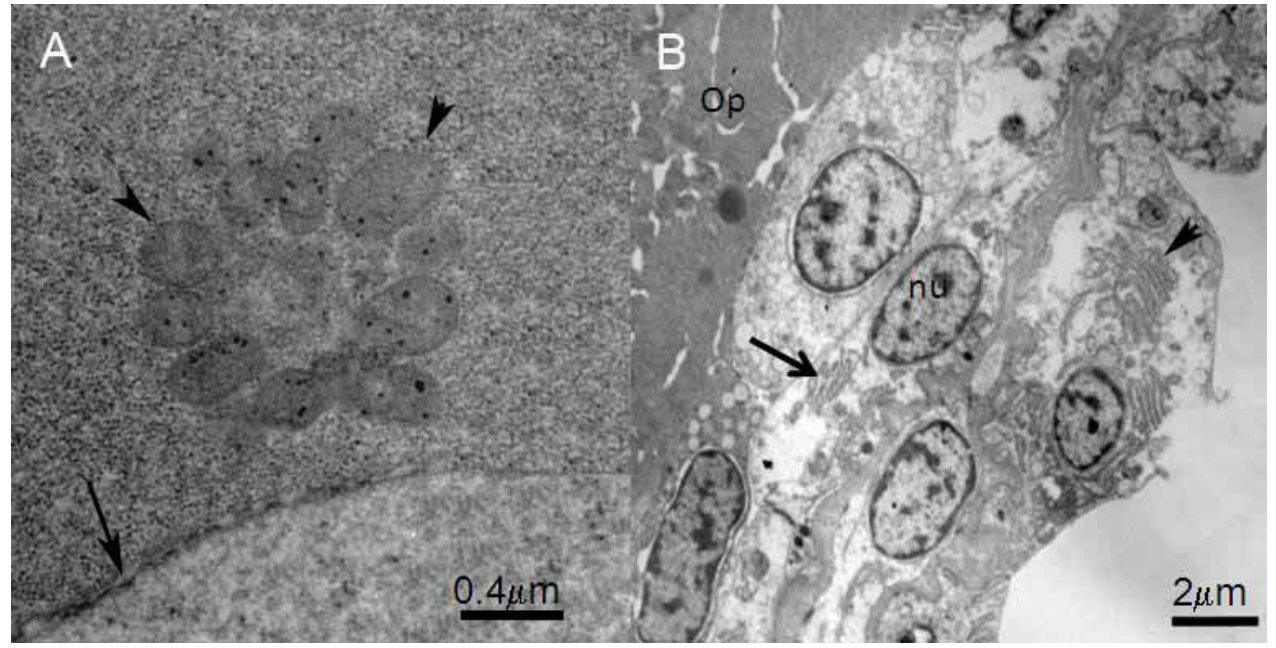

Fig. 2. Previtellogenic oocyte of Chiton virgulatus. A) Mitochondria (arrowheads) in the oocyte cytoplasm, nuclear pore (arrow). Bar scale $=0.4 \mu \mathrm{m}$. B) Follicular cells of Chiton virgulatus, (nu) nucleus, (arrow) smooth endoplasmic reticulum, (arrowhead) Golgi apparatus, (op) previtellogenic oocyte. Transmission electron microscopy. Bar scale $=2 \mu \mathrm{m}$

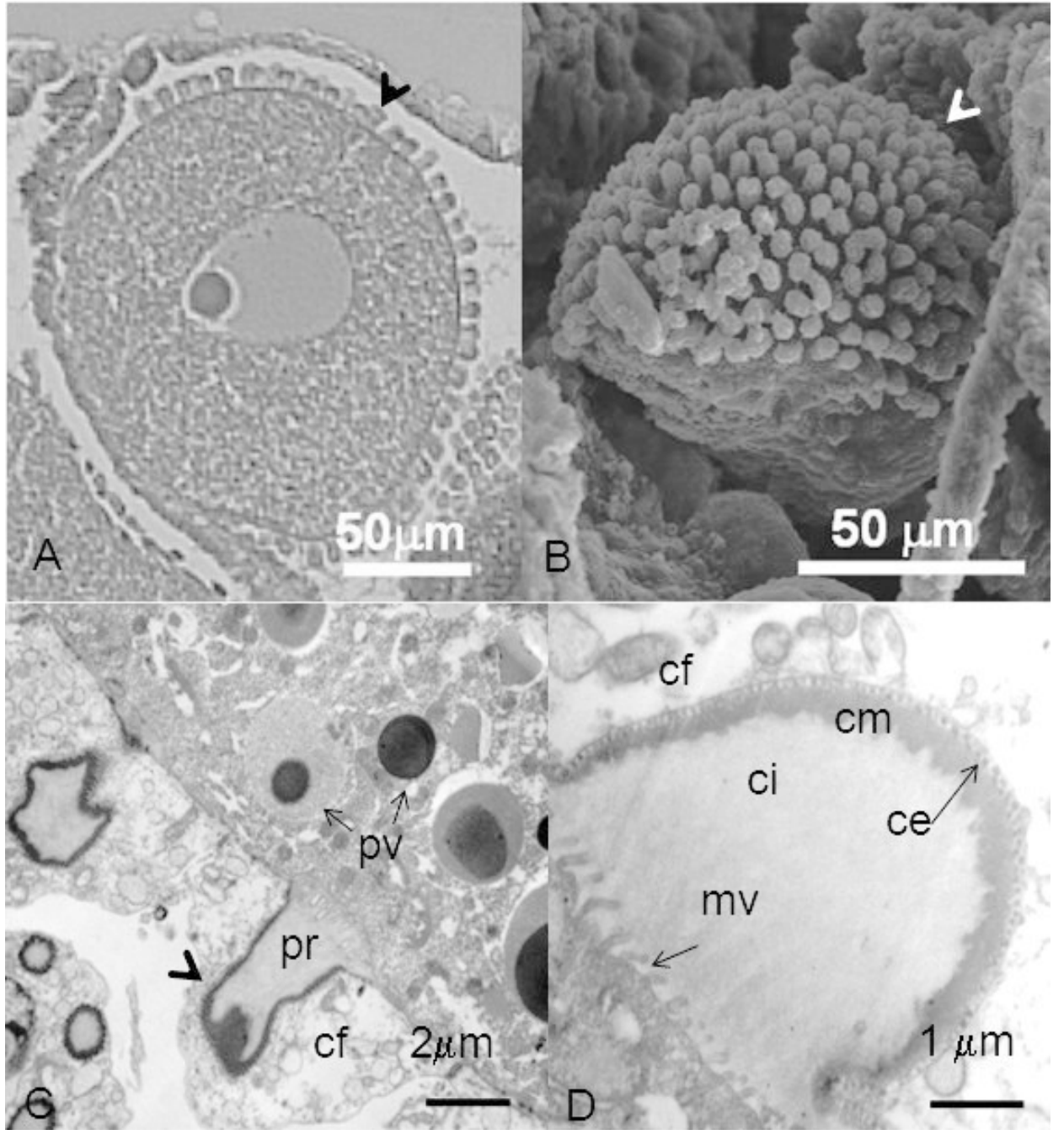

610
Fig. 3. Immature vitellogenic oocytes of Chiton virgulatus. Oocyte hull projections (arrow heads). Hematoxylin-eosin staining, bar scale $=50 \mu \mathrm{m}$. B) Scanning electron microscopy. Bar scale $=50$ $\mu \mathrm{m}$. C) Transmission electron microscopy, numerous vitelline platelets (pv), projection of the oocyte hull (pr), follicular cell (cf). Bar scale $=2 \mu \mathrm{m}$. D) Structure of an oocyte hull projection: inner layer (ci), middle layer $(\mathrm{cm})$, outer layer (ce), microvilli (mv). Transmission electron microscopy. Bar scale $=1$ $\mu \mathrm{m}$. 


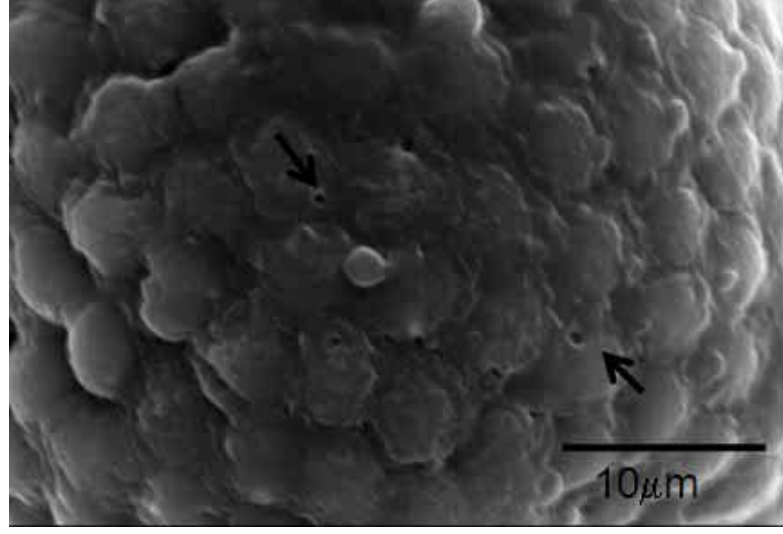

Fig. 4. Immature vitellogenic oocytes of Chiton virgulatus showing the pores adjacent to the projections (arrows). Scanning electron microscopy. Bar scale $=10 \mathrm{~mm}$.

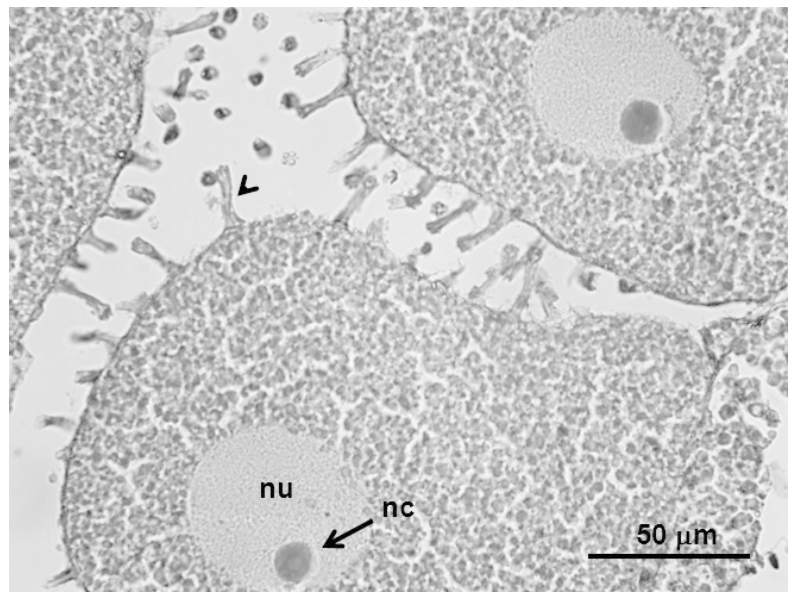

Fig. 5. Mature vitellogenic oocyte of Chiton virgulatus . Oocyte hull projections (arrow), (nu) nucleus, (nc) nucleolus. Hematoxylin-eosin staining, bar scale $=50 \mu \mathrm{m}$.

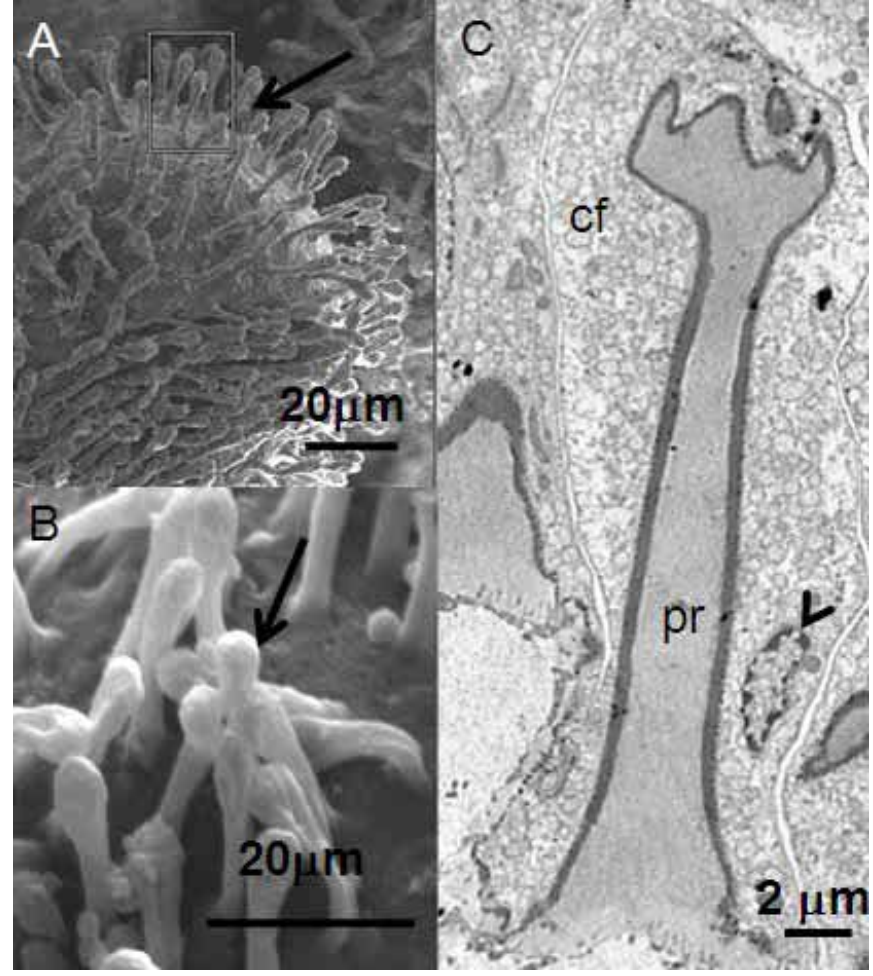

Fig. 6. A) Mature vitellogenic oocyte of Chiton virgulatus. Bar scale $=20 \mu \mathrm{m}$. B) Oocyte hull projections (arrow). Scanning electron microscopy. Bar scale $=20 \mu \mathrm{m}$. C) Hull projection of a mature vitellogenic oocyte of Chiton virgulatus. Follicular cell (cf) surrounding the projection (pr). Transmission electron microscopy. Bar scale $=2 \mu \mathrm{m}$

Mature vitellogenic oocytes range between 100 and 301 $\mu \mathrm{m}$ in diameter, averaging $146 \pm 24.8 \mu \mathrm{m}$ (Fig. $6 \mathrm{~A}$ ), and are extremely acidophilic. The cytoplasm is composed primarily of vitelline platelets that mask other organelles (Fig. 7B), and only a few mitochondria ( $0.5 \mu \mathrm{m}$ mean diameter) are observed; the cytoplasmic projections of the oocyte growth and its apical zone becomes trident-shaped (Fig. 6C). Follicular cells adopt a bulbous shape due to the

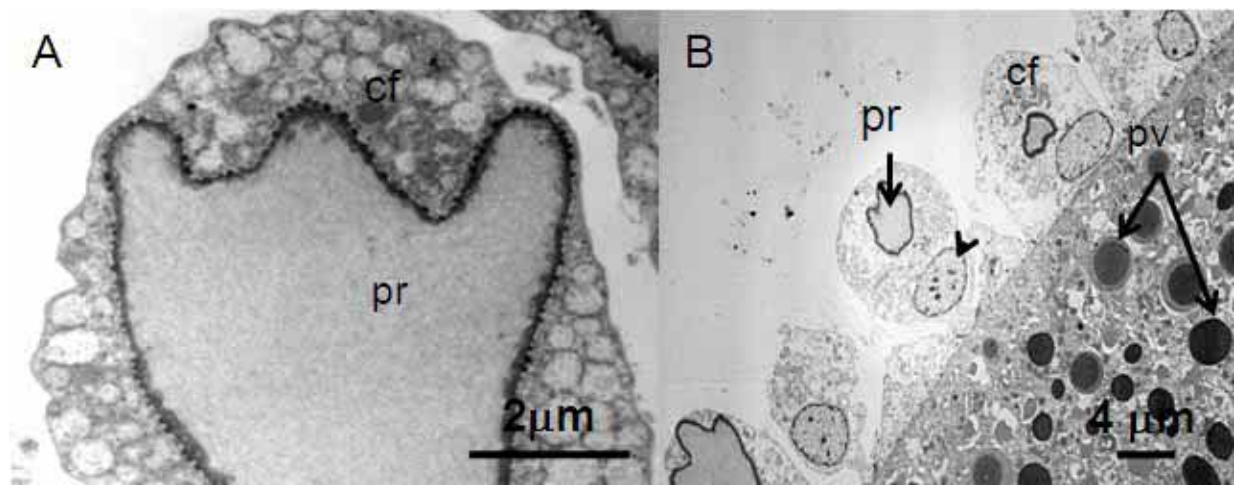
growth of the elongation and can reach up to $20 \mu \mathrm{m}$ in length (Figs. 6A and B).

Fig. 7. A) Apical portion of a projection of the hull of a Chiton virgulatus mature vitellogenic oocyte. Bar scale $=2 \mu \mathrm{m}$. B) Mature vitellogenic oocyte, follicular cell (cf), projection (pr), follicular cell nucleus (arrowhead), vitelline platelets (pv). Transmission electron microscopy. Bar scale $=4 \mu \mathrm{m}$. 


\section{DISCUSSION}

Similar to bivalves such as Meretrix luoria (Röding, 1798; in Chung, 2007) and other polyplacophora such as Chiton tuberculatum Linnaeus, 1758 (Cowden), Chiton iatricus Winckworth, 1930 (Deshpande \& Nagabhushanam), Chiton cumingsii Frembly, 1827 (Sotil) and Acanthopleura gemmata Blainville, 1825 (Barbosa et al., 2009), Chiton virgulatus displays three oocyte types: previtellogenic oocytes, immature vitellogenic oocytes and mature vitellogenic oocytes. These cells develop from oogonia (Cowden), which increase in volume by accumulating reserves as they mature (Pazos et al., 1996). According to Sotil, the basophilic character and the presence of numerous vacuoles in previtellogenic oocytes is due to the presence of acid mucopolysaccharides together with lipid-containing vesicles that increase in number and are dispersed, evidencing intracellular transport activity and substance accumulation. Such vacuoles were also observed in Rhyssoplax tulipa by Buckland-Nicks \& Reunov, who point out that these are released by exocytosis to form intercellular spaces between the follicular cell and the oocyte which, afterwards, will produce the oocyte projections.

Likewise, vitellogenic oocytes display vitelline platelets and a lower number of vacuoles because they accumulate nutrients as vitellum granules and lipid vesicles scattered throughout the cytoplasm, as in some marine invertebrates (Pazos et al.). Sotil points out that vitellogenesis is an important energy-demanding process, with the formation of vitellum granules mainly composed of lipid and protein substances.

Some researchers believe that oocyte projections are a sort of corium formed from follicular cells, and that these cells also determine corium size and structure (Sotil). However, this study revealed that in $C$. virgulatus the oocyte hull consists of cytoplasm projections and follicular cells similar to those described for Lepidochitona cinerea (Linnaeus, 1767) (cited in Richter, 1986), Lepidochitona hartwegii (Carpenter, 1855), Lepidochitona berryana (Eernisse, 1986), Lepidochitona caverna (Eernisse, 1986), Lepidochitona denties (Gould, 1846) (cited in Eernisse \& Reynolds), and Rhyssoplax tulipa (Quoy \& Gaimard, 1835) (cited in Buckland-Nicks \& Reunov). These authors point out that follicular cells function as a template for the deposition of mucopolysaccharides and proteins constituting the oocyte hull; hence, oocyte projections in $C$. virgulatus consist of the three layers previously described by Selwood (1970) for Sypharochiton septentriones and Buckland-Nicks \& Reunov for R. tulipa. It is likely that these secretions also have a micro-aprocrine extrusion mechanism by oocyte follicular cells.
Members of the family Chitonidae display conspicuous projections shaped as domes, cups, cones, fins, spiral tips or spines (Eernisse \& Reynolds; Buckland-Nicks \& Hodgson; Sotil; Buckland-Nicks \& Brothers; Ituarte et $a l . ;$ Liuzzi \& Zelaya). The shape of these projections improves flotation in the water column and allows the formation of chains with floating debris, thus ensuring fertilization (Buckland-Nicks \& Hodgson; Buckland-Nicks \& Brothers). The trident-shaped morphology coated by follicular cells that gives the bulbous appearance to $C$. virgulatus oocytes could be a species-specific trait involved in fertilization, as could also be the diameter of pores adjacent to those projections, which is smaller than the one reported for other species such as Collochiton casteneus Wood, 1815 (Buckland-Nicks \& Hodgson), but larger than the one reported for Ischnochiton stramineus (Sowerby in Broderip \& Sowerby, 1832) (cited in Liuzzi \& Zelaya). It is concluded that Chiton virgulatus shows the same cell types typical of the oogenesis of other Chiton species, as well as a mature vitellogenic oocyte with numerous projections the ultrastructure of which is a trident-shaped bulbous appearance; both features could be used as taxonomic criteria in future phenotypic analyses.

\section{ACKNOWLEDGEMENTS}

The authors thank the Department of Research and Postgraduate Studies of the National Polytechnic Institute (IPN) for funding this project and the Commission for the Operation and Promotion of Academic Activities, IPN for grants awarded to F. García-Domínguez, M. ArellanoMartínez and N. Vélez-Arellano. Also thanks to S. GonzálezPozos for her technical assistance in transmission electron microscopy, and to María Elena Sánchez Salazar for her editorial help on the English manuscript.

VÉLEZ-ARELLANO, N.; SHIBAYAMA, M.; ORTÍZORDOÑEZ, E.; SILVA-OLIVARES ANGÉLICA; ARELLANO-MARTÍNEZ, M. \& GARCÍA-DOMÍNGUEZ, F. Descripción histológica de la ovogénesis de Chiton virgulatus (Mollusca: Polyplacophora). Int. J. Morphol., 32(2):608-613, 2014.

RESUMEN: En el presente trabajo se describe la ovogénesis de Chiton virgulatus, utilizando histología y las técnicas de microscopía electrónica de barrido y de transmisión. Se identificaron tres tipos de ovocitos: i) ovocitos previtelogénicos con un diámetro promedio de $50 \pm 20,5 \mu \mathrm{m}$, rodeados por células foliculares de forma alargada y un tamaño de aproximadamente 
$5 \mu \mathrm{m}$, ii) ovocitos vitelogénicos inmaduros con un diámetro promedio de $113 \pm 15,3 \mu \mathrm{m}$, este tipo de ovocitos presentan pequeñas proyecciones citoplasmáticas, que indican el inicio del desarrollo del casco del ovocito. Adyacentes a cada prolongación se presentan poros con un diámetro aproximado de $0,7 \mu \mathrm{m}$ y iii) ovocitos vitelogénicos maduros con un diámetro promedio de $146 \pm 24,8$ $\mu \mathrm{m}$, las proyecciones citoplasmáticas del casco del ovocito crecen y en su parte apical adquieren la forma de un tridente, las células foliculares, dado el crecimiento de la prolongación toman el aspecto bulboso y llegan a medir hasta $20 \mu \mathrm{m}$ de longitud. La morfología y la ultraestructura de las proyecciones del casco del ovocito vitelogénico maduro, así como el tamaño del poro en la base de las proyecciones son particulares para C. virgulatus, dichas características podrían ser utilizadas en trabajos de taxonomía y fertilización.

PALABRAS CLAVE: Casco del ovocito; Vitelogénesis; Ultraestructura.

\section{REFERENCES}

Barbosa, S. S.; Byrne, M. \& Kelaher, B. P. Reproductive periodicity of the tropical intertidal chiton Acanthopleura gemmata at One Tree Island, Great Barrier Reef, near its southern latitudinal limit. J. Mar. Biol. Assoc. U. K., 89(2):405-11, 2009.

Buckland-Nicks, J. Fertilization biology and the evolution of chitons. Am. Malacol. Bull., 25(1):97-111, 2008.

Buckland-Nicks, J. \& Hodgson, A. N. Fertilization in Callochiton castaneus (Mollusca). Biol. Bull., 199(1):59-67, 2000.

Buckland-Nicks, J. \& Brothers, E. On fertilization in Chaetopleura apiculata and selected Chitonida. Biol. Bull., 214(2):184-93, 2008 .

Buckland-Nicks, J. \& Reunov, A. Ultrastructure of hull formation during oogenesis in Rhyssoplax tulipa (=Chiton tulipa) (Chitonidae: Chitoninae). Invertebr. Reprod. Dev., 53(3):165174, 2009.

Chung, E. Y. Oogenesis and sexual maturation in Meretrix lusoria (Roding 1798) (Bivalvia: Veneridae) in western Korea. $J$. Shellfish Res., 26(1):71-80, 2007.

Cowden, R. A. Cytochemical investigation of oogenesis and development to the swimming larval stage in the chiton, Chiton tuberculatus. Biol. Bull., 120:313-25, 1961.

Deshpande, U. D. \& Nagabhushanam, R. Oogenesis in the Amphinuran Chiton, Chiton iatricus. Proc. Indian Natl. Sci. Acad., B49(6):613-9, 1983.

Eernisse, D. J. Reproductive patterns in six species of Lepidochitona (Mollusca: Polyplacophora) from the Pacific Coast of North America. Biol. Bull., 174:287-302, 1988.
Eernisse, D. J. \& Reynolds, P. D. Polyplacophora. In: Harrison, F. W. \& Kohn, A. J. (Eds.). Microscopic anatomy of invertebrates. Vol. 5. Mollusca I. New York, Wiley-Liss, 1994.

Ituarte, C.; Liuzzi, M. G. \& Centurión, R. Egg Hull Morphology in Two Chitons (Polyplacophora) from the Southwestern Atlantic Ocean. Malacologia, 53(1):167-74, 2010.

Liuzzi, M. G. \& Zelaya, D. G. Egg-Hull Ultrastructure of Ischnochiton stramineus (Sowerby, 1832), A South American brooding chiton (Chitonina: Ischnochitonidae). J. Molluscan Stud., 79(4):372-377, 2013.

Pazos, A. J.; Román, G.; Acosta, C. P.; Abad, M. \& Sánchez, J. L. Influence of the gametogenic cycle on the biochemical composition of the ovary of the great scallop. Aquacul. Int., 4(3):201-13, 1996.

Richter, H. P. Ultrastructure of Follicular Epithelia in the Ovary of Lepidochitona cinerea (L.) (Mollusca: Polyplacophora). Dev. Growth Differ., 28(1):7-16, 1986.

Selwood, L. The role of the follicle cells during oogenesis in the Chiton Sypharochiton septentriones (Ashby) (Polyplacaphora, Mollusca). Z. Zellforsch., 104:178-92, 1970.

Sirenko, B. Relict settlement of the chiton Lepidochitona cinerea Mollusca, Polyplacophora in northern Norway. Arch. Fish. Mar. Res., 46(2):139-49, 1998.

Sotil, C. G. E. Variación estacional de la madurez gonadal y oogénesis de Chiton cumingsii Frembly, 1827 de Bahía Ancón, Lima-Peru. Tesis de Licenciatura. Lima, Perú, Universidad Nacional Mayor de San Marcos, 2004.

\section{Correspondence to:}

Federico García-Domínguez

Centro Interdisciplinario de Ciencias Marinas

Instituto Politécnico Nacional

Av. IPN s/n. Col. Playa Palo de Santa Rita

La Paz, B.C.S., C.P. 23096

MÉXICO

Email: fdoming@ipn.mx

Received: 11-02-2014

Accepted: 21-04-2014 